\title{
Analisis Produksi Jagung Kuning di Desa Bahutara, Kecamatan Kontukowuna, Kabupaten Muna
}

\author{
La Sinaini ${ }^{1 *}$ \\ ${ }^{1}$ Program Studi Agribisnis, Sekolah Tinggi Ilmu Pertanian Wuna Raha \\ *Corresponding author: lasinaini81@gmail.com
}

\begin{abstract}
Abstrak
Peningkatan produksi jagung seyogyanya diiringi dengan peningkatan produktivitas karena akan berdampak pada penigkatan pendapatan petani. Tujuan penelitian adalah untuk menganaslisis faktor-faktor yang mempengaruhi produksi jagung kuning di Desa Bahutara Kecamatan Kontukowuna Kabupaten Muna. Penelitian ini dilaksanakan pada bulan Juni 2018 sampai dengan bulan Agustus 2018. Lokasi penelitian ditentukan secara purposive (sengaja) yaitu Desa Bahutara Kecamatan Kontukowuna Kabupaten Muna karena merupakan salah satu sentra produksi tanaman jagung kuning di Kecamatan Kontukowuna Kabupaten Muna. Sumber data yang digunaan dalam penelitian ini adalah data primer dan data sekunder. Data primer diperoleh dari responden petani jagung di Desa Bahutara dengan metode acak sederhana, sedangkan data sekunder diperoleh dari Badan Pusat Statistik Kabupaten Muna dan Profil Desa Bahutara. Metode analisis data yang digunakan dalam penelitian ini adalah analisis fungsi produksi Cobb-Douglass, dengan menggunakan alat bantu softwere SPSS versi 16. Hasil Penelitian menunjukkan secara simultan faktor luas lahan, benih, pupuk urea, dan pupuk NPK Phonska berpengaruh signifikan terhadap produksi jagung kuning di Desa Bahutara, Kecamatan Kontukowuna Kabupaten Muna, sedangkan secara parsial hanya faktor benih berpengaruh signifikan terhadap produksi jagung kuning di Desa Bahutara, Kecamatan Kontukowuna Kabupaten Muna. Usaha tani jagung kuning di Desa Bahutara dapat ditingkatkan perlu dilakukan pengoahan lahan yang baik, pemberian pupuk urea dan pupuk NPK Phonska secara berimbang terhadap jagung kuning.
\end{abstract}

Kata kunci: Jagung kuning, Faktor produksi, Produksi

\begin{abstract}
Increasing maize production should be accompanied by increased productivity because it will have an impact on increasing farmers' income. The research objective was to analyze the factors that influence the production of yellow maize in Bahutara Village, Kontukowuna Sub-District, Muna Regency. This research was conducted from June 2018 to August 2018. The research location was determined purposively, namely Bahutara Village, Kontukowuna Sub-District, Muna Regency because it is one of the production centers for yellow maize in Kontukowuna Sub-District, Muna Regency. Sources of data used in this study are primary data and secondary data. Primary data was obtained from maize farmer respondents in Bahutara Village using a simple random method, while secondary data was obtained from the Central Statistics Agency of Muna Regency and the Village Profile of Bahutara. The data analysis method used in this study was the analysis of the Cobb-Douglass production function, using the SPSS version 16 software tool. The results showed that simultaneously the land area, seeds, urea fertilizer and NPK Phonska fertilizer had a significant effect on the production of yellow maize in Bahutara Village, Kontukowuna ub-District, Muna Regency, while only partially the seed factor has a significant effect on yellow maize production in Bahutara Village, Kontukowuna Sub-District, Muna Regency. The yellow corn farming business in Bahutara Village can be improved, it is necessary to carry out good land processing, provision of urea and NPK Phonska fertilizer in a balanced manner against yellow maize.
\end{abstract}

Keywords: Yellow maize, Factors of production, Production 
Prosiding Seminar Nasional Pembangunan dan Pendidikan Vokasi Pertanian Politeknik Pembangunan Pertanian Manokwari, 14 November 2020

e ISSN : 2774-1982

\section{PENDAHULUAN}

Jagung merupakan komoditas tanaman pangan yang memiliki peranan penting dan strategis setelah padi dalam pembangunan nasional. Jagung selain digunakan untuk bahan pangan, pipilan keringnya juga dapat digunakan sebagai pakan ternak dan bahan baku industri pakan. Komoditas jagung tergolong komoditas yang strategi dan memiliki prospek pemasaran yang baik. Peningkatan kebutuhan jagung dalam negeri berkaitan erat dengan perkembangan industri pangan dan pakan. Oleh sebab itu, upaya peningkatan produksi jagung perlu mendapat perhatian yang lebih besar (Subandi et al., 1998).

Pola konsumsi jagung oleh masyarakat Indonesia selain dikonsumsi langsung, jagung digunakan sebagai pakan ternak dan juga sebagai bahan baku industri. Industri pakan ternak menjadi konsumen utama dalam kegiatan produksi jagung mengingat laju pertumbuhan penduduk Indonesia yang semakin meningkat, seiring dengan peningkatan pendapatan, dan kesadaran masyarakat meningkat akan pemenuhan kebutuhan protein hewani. Oleh karena itu, jagung merupakan komoditas yang mempunyai nilai strategis seperti halnya beras Nuryartono (2010).

Program swasembada jagung yang dicanangkan oleh pemerintah membutuhkan kerjasama yang baik dari petani maupun pemerintah. Setidaknya ada dua indikator utama pencetus keberhasilan pencapaian swasembada jagung, pertama adalah peningkatan luas tanam, indikator kedua yakni peningkatan produktivitas dengan penggunaan bibit unggul (Satyadarma, 2010). Tetapi kendala utama yang dihadapi dalam peningkatan produktivitas baik di Pulau Jawa maupun di luar Pulau Jawa yakni alih fungsi lahan pertanian menjadi kawasan industri dan pemukiman yang semakin meningkat. Sehingga salah satu solusi yang dapat diterapkan yakni dengan cara mengintensifkan lahan pertanian yang ada agar produktivitas meningkat. Kendala lain yang sering dihadapi yakni keterbatasan petani dalam mengalokasikan faktor-faktor produksi yang ada sehingga pencapaian produktivitas belum optimal.

Kabupaten Muna merupakan salah satu daerah sentra produksi jagung di Propinsi Sulawesi Tenggara. Namun dalam lima tahun terakhir produksi jagung di Kabupaten Muna cenderung mengalami penurunan produksi. Data produksi jagung lima tahun terakhir Kabupaten Muna yaitu 2015 sebanyak 32.007 ton atau turun 10,56\% tahun sebelumnya, tahun 2016 sebanyak 19.352 ton atau turun 39,54\%, tahun 2017 sebanyak 35.157 ton atau naik 81,67\%, tahun 2018 sebanyak 32.602,2 ton atau turun 7,27\%, dan tahun 2019 sebanyak 22.816 ton atau turun 30,02\% (BPS Kab. Muna, 2020). 
Prosiding Seminar Nasional Pembangunan dan Pendidikan Vokasi Pertanian Politeknik Pembangunan Pertanian Manokwari, 14 November 2020

e ISSN : 2774-1982

Kegiatan usahatani dapat meningkatkan keuntungan jika produsen dapat mengelola faktor produksi dengan seefisien mungkin, karena keberhasilan usahatani tidak hanya dilihat dari segi tingginya produksi yang dapat dihasilkan, tetapi juga penggunaan faktor produksi dalam proses produksi harus sefisien mungkin, sehingga tidak hanya produktivitas yang meningkat tetapi juga keuntungan yang diterima (Purwanto, 2008). Tidak tercapainya efisiensi dalam berusahatani antara lain disebabkan oleh kurangnya pengetahuan dalam menggunakan faktor produksi yang terbatas, kesulitan petani dalam memperoleh faktor produksi dalam jumlah yang tepat serta adanya faktor luar yang menyebabkan usahatani menjadi tidak efisien seperti keadaan iklim, kondisi geografis, suhu, dan sebagainya (Soekartawi, 1991).

Peningkatan produksi jagung seyogyanya diiringi dengan peningkatan produktivitas karena akan berdampak pada penigkatan pendapatan petani. Peningkatan produktivitas jagung dari setiap lahannya, petani dihadapkan pada suatu masalah yakni keterbatasan dalam memanfaatkan segala faktor produksi dalam proses pembudidayaan jagung dan berakibat pada belum maksimalnya hasil produksi yang didapat. Oleh karena itu, dibutuhkan pengkombinasian penggunaan faktor produksi seperti benih, pupuk kimia, pestisida, dan tenaga kerja yang sesuai, sehingga penelitian penggunaan faktor input produksi sangat penting dilakukan, agar dapat diketahui pengaruh penggunaan input yang digunakan petani dalam rangka peningkatan produksi jagung di Kabupaten Muna.

Salah satu daerah pengembangan jagung kuning di Kabupaten Muna yaitu di Desa Bahutara Kecamatan Kontukowuna, namun sejauh ini belum diketahui bagaimana pengaruh penggunaan input produksi yang digunakan petani terhadap produksi yang dihasilkan petani jagung di daerah tersebut. Penggunaan input usahatani jagung yang digunakan petani diharapkan dapat meningkatkan produktivitas jagung kuning sehingga pendapatan mereka juga meningkat. Oleh karena itu tujuan penelitian ini yaitu menganalisis faktor-faktor yang mempengaruhi produksi jagung kuning di Desa Bahutara Kecamatan Kantukowuna.

\section{METODE}

Penelitian ini dilaksanakan di Desa Bahutara Kecamatan Kontukowuna Kabupaten Muna pada bulan Juni 2018 sampai dengan bulan Agustus 2018.. Lokasi penelitian ditentukan secara purposive (sengaja) karena merupakan salah satu sentra produksi tanaman jagung kuning di Kecamatan Kontukowuna Kabupaten Muna. Populasi penelitian ini adalah seluruh petani jagung di Desa Bahutara yaitu sebanyak 135 orang. 
Prosiding Seminar Nasional Pembangunan dan Pendidikan Vokasi Pertanian

Politeknik Pembangunan Pertanian Manokwari, 14 November 2020

e ISSN : 2774-1982

Penentuan sampel menggunakan metode simple random sampling dengan pertimbangan setiap unit penelitian atau satuan elementer dari populasi mempunyai kesempatan yang sama untuk dipilih sebagai sampel. Untuk mendapatkan sampel yang menggambarkan populasi, maka dalam penentuan sampel penelitian ini digunakan rumus Slovin. Menurut Umar (2003) dalam Budi (2011), rumus slovin digunakan untuk menentukan berapa minimal sampel yang akan dibutuhkan jika ukuran populasi diketahui dengan persamaan sebagai berikut:

$$
\mathrm{n}=\frac{N}{1+N e^{2}}
$$

Dimana :

$$
\begin{aligned}
& \mathrm{n}=\text { ukuran sampel } \\
& \mathrm{N}=\text { ukuran populasi } \\
& \mathrm{e}=\text { derajat kesalahan }
\end{aligned}
$$

Dari jumlah populasi tersebut dengan tingkat kesalahan sebesar 15\%, maka dengan menggunakan rumus diatas diperoleh sampel sebesar :

$$
\mathrm{n}=\frac{135}{1+135\left(15^{2)}\right.}=34
$$

Slovin masih memberi kebebasan untuk menentukan nilai batas kesalahan atau galat pendugaan. Oleh karena itu peneliti menentukan galat pendugaan sebesar $15 \%$, sehingga jumlah sampel dalam penelitian ini sebanyak 34 responden.

Data yang dikumpulkan dalam penelitian ini terdiri dari data primer dan data sekunder. Data primer merupakan hasil wawancara peneliti langsung dengan responden yang menjadi sampel dengan daftar kuesioner yang telah disiapkan sebelumnya. Sedangkan data sekunder berupa data atau dokumen yang berasal dari buku, internet, instansi terkait, surat kabar, penelitian terdahulu yang terkait dengan bahan penelitian. Data yang diperoleh diantaranya adalah data produksi jagung dari BPS, dan profil Desa Bahutara Kecamatan Kontukowuna Kabupaten Muna.

Analisis data yang digunakan yaitu analisis fungsi produksi Cobb-Douglas. Secara matematis dapat dituliskan sebagai berikut:

$$
\mathbf{Y}=\mathbf{b 0} \mathbf{X}_{\mathbf{1}}{ }^{\mathrm{b} 1} \mathbf{X}_{2}{ }^{\mathrm{b} 2} \mathbf{X}_{3}{ }^{\mathrm{b3}} \mathbf{X}_{\mathbf{4}}{ }^{\mathrm{b} 4} \mathbf{e} \text {. }
$$

Untuk mempermudah perhitungan, dari fungsi (3.6) tersebut kemudian diubah dalam bentuk logaritma linier, sehingga persamaannya menjadi:

$$
\operatorname{LnY}=\operatorname{Lnb}_{0}+b_{1} \operatorname{LnX}_{1}+b_{2} \operatorname{LnX}_{2}+b_{3} \operatorname{Ln} X_{3}+b_{4} \operatorname{LnX} X_{4}+
$$


Prosiding Seminar Nasional Pembangunan dan Pendidikan Vokasi Pertanian Politeknik Pembangunan Pertanian Manokwari, 14 November 2020

e ISSN : 2774-1982

Dimana :

$$
\begin{array}{ll}
\mathrm{Y} & =\text { produksi jagung }(\mathrm{kg}) \\
\text { bo } & =\text { konstanta } \\
\mathrm{b} 1-\mathrm{b} 4 & =\text { koefisien regresi } \\
\mathrm{X}_{1} & =\text { luas lahan usahatani jagung }(\mathrm{ha}) \\
\mathrm{X}_{2} & =\text { benih }(\mathrm{kg}) \\
\mathrm{X}_{3} & =\text { pupuk urea }(\mathrm{kg}) \\
\mathrm{X}_{4} & =\text { pupuk NPK Phonska }(\mathrm{kg}) \\
\mathrm{e} & =\text { eror term }
\end{array}
$$

\section{HASIL DAN PEMBAHASAN}

\section{Karakteristik Usahatani Jagung}

Karakteristik usahatani jagung yang dianalisis dalam penelitian ini yaitu luas lahan usahatani jagung, jumlah benih, jumlah pupuk Urea, dan Jumlah pupuk NPK Phonska. Luas lahan yang diusahakan petani jagung yaitu berkisar antara 0,5 Ha sampai dengan 3 Ha. Adapun luas lahan usahatani jagung yang diusahakan petani responden yaitu disajikan pada Tabel 1.

Tabel 1. Sebaran Responden Berdasarkan Luas Lahan Usahatani Jagung

\begin{tabular}{cccc}
\hline No & Luas lahan (Ha) & Jumlah Responden (org) & Persentase $(\%)$ \\
\hline 1 & $<1$ & 4 & 11,76 \\
2 & $1-2$ & 28 & 82,36 \\
3 & $>2$ & 2 & 5,88 \\
\hline & Jumlah & 34 & 100,00 \\
\hline
\end{tabular}

Data Primer Diolah Tahun 2018

Tabel 1 menunjukkan bahwa luas lahan yang dimiliki responden bervariasi. Responden yang memiliki luas lahan usahatani jagung lebih kecil dari 1 Ha yaitu sebanyak 4 orang atau 11,76\%, yang memiliki luas lahan 1-2 Ha yaitu sebanyak 28 orang atau 82,36\%, dan yang memiliki lebih besar dari 2 Ha yaitu sebanyak 2 orang atau 5,88\%. Hal ini menunjukkan bahwa petani di Desa Bahutara mayoritas memiliki lahan usahatani jagung antara 1 -2 Ha. Benih jagung yang digunakan responden yaitu Varietas Bisi-2. Jumlah benih jagung yang digunakan berkisar antara 8 - $45 \mathrm{~kg}$. Adapun sebaran responden dapat dilihat pada Tabel 2 . 
Prosiding Seminar Nasional Pembangunan dan Pendidikan Vokasi Pertanian Politeknik Pembangunan Pertanian Manokwari, 14 November 2020

e ISSN : 2774-1982

Tabel 2. Sebaran Responden Berdasarkan Jumlah Benih Jagung yang Digunakan

\begin{tabular}{cccc}
\hline No & Jumlah Benih (Kg) & $\begin{array}{c}\text { Jumlah Responden } \\
\text { (org) }\end{array}$ & Persentase (\%) \\
\hline 1 & $<10$ & 1 & 2,94 \\
2 & $10-30$ & 31 & 91,18 \\
3 & $>30$ & 2 & 5,88 \\
\hline & Jumlah & 34 & 100,00 \\
\hline
\end{tabular}

Data Primer Diolah Tahun 2018

Tabel 2 menunjukkan bahwa responden yang menggunakan benih jagung lebih kecil dari $10 \mathrm{~kg}$ yaitu sebanyak 1 orang atau 2,94\%, yang menggunakan benih jagung anatara 10 - $30 \mathrm{~kg}$ yaitu sebanyak 31 orang atau 91,18\%, dan yang menggunakan benih jagung lebih besar dari $30 \mathrm{~kg}$ yaitu sebanyak 2 orang atau 5,88\%. Kondisi ini menandakan bahwa petani jagung di Desa bahutara rata-rata jagung yang digunakan yaitu sebanyak 10 - $30 \mathrm{~kg}$. Berdasarkan hasil penelitian jenis pupuk yang digunakan responden yaitu jenis pupuk Urea dan pupuk NPK Phonska. Adapun jumlah pupuk urea yang digunakan responden dapat dilihat pada Tabel 3.

Tabel 3. Sebaran Responden Berdasarkan Jumlah Pupuk Urea yang Digunakan

\begin{tabular}{cccc}
\hline No & Pupuk Urea (kg) & $\begin{array}{c}\text { Jumlah Responden } \\
\text { (org) }\end{array}$ & Persentase (\%) \\
\hline 1 & $<100$ & 1 & 2,94 \\
2 & $100-200$ & 27 & 79,41 \\
3 & $>200$ & 6 & 17,65 \\
\hline & Jumlah & 34 & 100,00 \\
\hline
\end{tabular}

Data Primer Diolah Tahun 2018

Tabel 3 menunjukkan bahwa reponden yang menggunakan pupuk urea lebih kecil dari $100 \mathrm{~kg}$, yaitu sebanyak 1 orang atau 2,94\%, yang menggunakan pupuk urea antara $100-200 \mathrm{~kg}$ yaitu sebanyak 27 orang atau $79,41 \%$, dan yang menggunakan pepuk urea lebih besar dari $200 \mathrm{~kg}$ yaitu sebanyak 6 orang atau 17,65\%. Kondisi ini menunukkan bahwa petani jagung di Desa Bahutara rata-rata menggunakan pupuk antara $100-200 \mathrm{~kg}$. Sedangkan jenis pupuk NPK Phonska yang digunakan dapat dilihat pada Tabel 4.

Tabel 4. Sebaran Responden Berdasarkan Jumlah Pupuk NPK Phonska

\begin{tabular}{cccc}
\hline No & Pupuk NPK Phonska (kg) & Jumlah Responden (org) & Persentase (\%) \\
\hline 1 & $<100$ & 1 & 2,94 \\
2 & $100-200$ & 22 & 64,71 \\
3 & $>200$ & 11 & 32,35 \\
& Jumlah & 34 & 100,00 \\
\hline
\end{tabular}

Data Primer Diolah Tahun 2018

Tabel 4 menunjukkan bahwa jumlah responden yang menggunakan pupuk NPK Phonska lebih kecil dari $100 \mathrm{~kg}$ yaitu sebanyak 1 orang atau 2,94\%, yang menggunakan 
Prosiding Seminar Nasional Pembangunan dan Pendidikan Vokasi Pertanian

Politeknik Pembangunan Pertanian Manokwari, 14 November 2020

e ISSN : 2774-1982

pupuk NPK Phonska antara 100-200 kg yaitu sebanyak 22 orang atau 64,71\%, dan yang menggunakan lebih besar dari $200 \mathrm{~kg}$ yaitu sebanyak 11 orang atau 32,35\%. Hal ini menunjukkan bahwa petani jagung di Desa Bahutararata-rata menggunakan pupuk NPK Phonska antara 100 - $200 \mathrm{~kg}$. Berdsarkan hasil penelitian roduksi jagung yang dihasilkan responden berkisar anatara $2.500 \mathrm{~kg}-10.000 \mathrm{~kg}$. Adapun sebaran responden dapat dilihat pada Tabel 5.

Tebel 5. Sebaran Responden Berdasarkan Jumlah Produksi Jagung

\begin{tabular}{cccc}
\hline No & Jumlah Prdoduksi (kg) & Jumlah Responden (org) & Persentase (\%) \\
\hline 1 & $<5.000$ & 21 & 61,76 \\
2 & $5.000-10.000$ & 13 & 38,24 \\
3 & $>10.000$ & 0 & 0,00 \\
\hline & Jumlah & 34 & 100,00
\end{tabular}

Data Primer Diolah Tahun 2018

Tabel 5 menunjukkan bahwa jumlah responden yang menghasilkan produksi jagung lebih keil dari $5.000 \mathrm{~kg}$ yaitu sebanyak 21 orang atau $61,76 \%$, yang menghasilkan $5.000 \mathrm{~kg}-10.000 \mathrm{~kg}$ yaitu sebanyak 13 orang atau 38,24\%. Kondisi ini menandakan bahwa rata-rata petani jagung di Desa Bahutara menghasilkan jagung antara $5.000 \mathrm{~kg}-$ $10.000 \mathrm{~kg}$ permusim tanam.

\section{Analisis Faktor-faktor yang Mempengaruhi Produksi Jagung}

Dalam penelitian ini variabel penelitian yang dianalisis mempengaruhi produksi jagung di Desa Bahutara yaitu luas lahan, benih, jumlah penggunaan pupuk urea, dan jumlah pupuk NPK Phonska. Analisis data yang digunakan dalam penelitian ini yaitu model fungsi produksi Cobb-Douglas. Berdasarkan alat analisis tersebut, maka variabel independent yaitu luas lahan, benih, jumlah penggunaan pupuk urea, dan jumlah pupuk NPK Phonska, sedangkan variabel dependent yaitu produksi. Adapun hasil estimasi pengaruh variabel independen terhadap variabel dependen disajikan pada Tabel 6. 
Prosiding Seminar Nasional Pembangunan dan Pendidikan Vokasi Pertanian Politeknik Pembangunan Pertanian Manokwari, 14 November 2020

e ISSN : 2774-1982

Tabel 6. Hasil Estimasi Faktor-faktor yang Mempengaruhi Produksi Jagung

\section{Coefficients $^{\mathrm{a}}$}

\begin{tabular}{|c|c|c|c|c|c|c|}
\hline \multirow{2}{*}{\multicolumn{2}{|c|}{ Model }} & \multicolumn{2}{|c|}{ Unstandardized Coefficients } & \multirow{2}{*}{$\begin{array}{c}\begin{array}{c}\text { Standardized } \\
\text { Coefficients }\end{array} \\
\text { Beta }\end{array}$} & \multirow[b]{2}{*}{$\mathrm{T}$} & \multirow[b]{2}{*}{ Sig. } \\
\hline & & B & Std. Error & & & \\
\hline \multirow[t]{5}{*}{1} & (Constant) & .596 & .623 & & .957 & .347 \\
\hline & Luas_lahan & -.609 & .757 & -.231 & -.805 & .428 \\
\hline & Benih & .189 & .055 & .912 & 3.432 & .002 \\
\hline & NPK & .001 & .004 & .029 & .146 & .885 \\
\hline & Urea & .006 & .006 & .212 & 1.071 & .293 \\
\hline 2 & $\mathrm{R}^{2}$ & .783 & & & & \\
\hline 3 & F-hit & 30.817 & & & & $.000^{\mathrm{a}}$ \\
\hline
\end{tabular}

a. Dependent Variable: Produksi

Tabel 6 tersebut dapat diturunkan dalam persamaan regresi sebagai berikut : LnY

$=1,596-0,609 \operatorname{LnX} 1+0,189 \operatorname{LnX} 2+0,001 \operatorname{LnX3}+0,006 \operatorname{LnX} 4$

Di mana :

LnY : Hasil Produksi Jagung $(\mathrm{Kg})$

LnX1 : Luas Lahan (m2)

LnX2 : Benih $(\mathrm{Kg})$

LnX3 : Pupuk NPK $(\mathrm{Kg})$

LnX4 : Pupuk urea $(\mathrm{Kg})$

Hasil uji F yang telah dilakukan melalui pengolahan data menggunakan SPSS versi 17 dalam penelitian ini, diperoleh nilai F-hitung sebesar 30,817. Sedangkan nilai Ftabel 2,69, dengan tingkat kepercayaan 95\% $(\alpha=0,05)$ untuk df $\mathrm{N} 1=4$ dan df $\mathrm{N} 2=30$ maka nilai F-tabel sebesar 2,69. Dari hasil tersebut dapat diambil kesimpulan bahwa nilai F-hitung $(30,817)>$ F-tabel $(2,69)$. F-hitung yang lebih besar dari F-tabel mempunyai arti bahwa secara bersama-sama dari semua variabel bebas luas lahan, benih, pupuk urea, dan pupuk NPK Phonska berpengaruh terhadap variabel terikat yaitu produksi usahatani jagung.

Sesuai dengan ketentuan uji koefisien determinasi bahwa apabila nilai $(\mathrm{R} 2)=1$, maka pengaruh variabel bebas terhadap naik turunnya variabel terikat adalah $100 \%$, sehingga tidak ada faktor lain yang mempengaruhi variabel terikat tersebut selain variabel bebas yang telah dimasukkan dalam model. Dalam penelitian ini nilai R2 sebesar 0,783. Nilai ini dapat dimaknai, bahwa varaibel bebas yang terdiri dari luas lahan, benih, pupuk urea, dan pupuk NPK Phonska yang dimasukkan kedalam model penelitian mampu 
Prosiding Seminar Nasional Pembangunan dan Pendidikan Vokasi Pertanian

Politeknik Pembangunan Pertanian Manokwari, 14 November 2020

e ISSN : 2774-1982

menjelaskan pengaruh produksi jagung sebesar 78,30\%, dan sisanya $11,70 \%$ dijelaskan oleh faktor lain yang tidak dimasukan dalam model penelitian.

Pada penelitian ini faktor yang berpengaruh terhadap produksi jagung dianalisis dengan regresi linear berganda dengan jumlah sampel 34. Uji statistik pada model persamaan regresi linear berganda dalam penelitian ini adalah uji t yang merupakan pengujian secara individual (parsial). Uji t dilakukan dengan membandingkan nilai thitung dengan nilai t-tabel, dengan tingkat kepercayaan 95\% $(\alpha=0.05)$ dan degree of freedom (df) dengan rumus n-1 sebesar 33, diperoleh nilai t-tabel sebesar 1,697. Hasil uji $\mathrm{t}$ tersebut adalah sebagai berikut :

1. Luas Lahan. Nilai koefisien regresi luas lahan adalah sebesar 0,609 dengan nilai thitung sebesar -0,805. Nilai ini lebih kecil dibandingkan dengan nilai t-tabel 1,697. Secara statistik luas lahan yang dialokasikan untuk usahatani jagung tidak berpengaruh nyata terhadap produksi jagung di daerah penelitian. Hal ini disebabkan lahan yang diolah petani jagung di Desa Bahutara belum diolah secara maksimal.

2. Benih. Nilai koefisien regresi pada benih adalah sebesar 0,189 dengan nilai t-hitung sebesar 3,432 lebih besar dari t-tabel 1,697. Secara statistik disimpulkan bahwa benih yang dialokasikan dalam usahatani jagung di daerah penelitian berpengaruh nyata terhadap produksi jagung. Hal ini dapat diartikan bahwa penggunaan benih dalam jumlah yang berbeda akan menghasilkan jumlah produksi yang berbeda pula. Adanya pengaruh benih terhadap produksi jagung disebabkan oleh pada fase pertumbuhan benih menyerap asupan air yang cukup sehingga tanaman jagung tumbuh dengan baik. Selain itu, penggunaan benih jagung jenis hibrida oleh petani di daerah penelitian, dan kegiatan penanaman maupun penjarangan yang tepat sehingga memungkinkan benih untuk tumbuh dengan baik. Nilai koefisien regresi sebesar 0,189 menunjukkan bahwa peningkatan pengalokasian benih sebesar 1\% akan menaikkan produksi sebesar $0,189 \%$.

3. Pupuk NPK Phonska. Nilai koefisien regresi pupuk NPK Phonska adalah 0,001 dengan nilai t-hitung sebesar 0,146 lebih kecil dari t-tabel 1,697. Secara statistik penggunaan pupuk NPK Phonska dalam usahatani jagung di daerah penelitian tidak berpengaruh nyata terhadap produksi jagung. Hal ini dapat disebabkan kondisi tanah pada masing-masing responden mempunyai tingkat kesuburan yang berbeda, disamping itu tingkat pengetahuan petani terhadap kesuburan tanahnya tidak diketahui sehingga pemberian pupuk yang dilakukan tidak sesuai anjuran pada kondisi tanah yang berbeda-beda tingkat kesuburannya.Pupuk Urea. Nilai koefisien 
Prosiding Seminar Nasional Pembangunan dan Pendidikan Vokasi Pertanian Politeknik Pembangunan Pertanian Manokwari, 14 November 2020

e ISSN : 2774-1982

regresi pada pupuk NPK Phonska adalah 0,006 dengan nilai t-hitung sebesar 0,146 lebih kecil dari t-tabel 1,697. Secara statistik penggunaan pupuk urea dalam usahatani jagung di daerah penelitian tidak berpengaruh nyata terhadap produksi jagung. Hal ini dapat disebabkan kondisi tanah pada masing-masing responden mempunyai tingkat kesuburan yang berbeda, disamping itu tingkat pengetahuan petani terhadap kesuburan tanahnya tidak diketahui sehingga pemberian pupuk yang dilakukan tidak sesuai anjuran pada kondisi tanah yang berbeda-beda tingkat kesuburannya.

\section{KESIMPULAN DAN SARAN}

Berdasakan hasil hasil penelitian faktor luas lahan, benih, pupuk urea, dan pupuk NPK Phonska, secara simultan mempengaruhi produksi jagung di Desa Bahutara Kabupaten Muna, sedangkan secara hanya benih yang tidak berpengaruh nyata terhadap produksi jagung kuning di Desa Bahutara, Kabupaten Muna. Saran yang dapat direkomendasikan dari hasil penelitian ini yaitu kepada petani agar meningkatkan penggunaan faktor produksi dengan menambah luas lahan usahatani jagung, meningkatkan penggunaan benih unggul, menggunakan pupuk urea dan pupuk NPK phonska sesuai anjuran. Kepada pemerintah agar memberikan perhatian kepada petani jagung kuning, dengan mengintensifkan kegiatan penyuluhan, sehingga petani dapat menerapkan budidaya jagung dengan benar, dan memberikan fasilitas pupuk urea dan pupuk NPK phonska dalam hal ketersediaannya sepanjang waktu. Kepada dunia akademisi agar penelitian ini dapat dijadiikan sebagai referinsi untuk melakukan menelitian dengan menamba variabel lainnya dalam menganalisis faktor-faktor yang mempengaruhi produksi jagung.

\section{DAFTAR PUSTAKA}

BPS Kabupaten Muna (2020). Muna Dalam Angka. https://munakab.bps.go.id/publication/2020/04/27/b97bd3328ded040baa6c5408/ka bupaten-muna-dalam-angka-2020.html. Diakses 15 Oktober 2020.

Budi, Putri. (2011). Analisis Efisiensi Teknis Penggunaan Faktor Produksi Pada Usahatani Jagung (Zea Mays)Di Desa Sukolilo, Kecamatan Wajak, Kabupaten Malang. Fakultas Pertanian. Universitas Brawijaya. Tidak di Publikasikan.

Nuryantono, Nunung. (2010). Akankah Indonesia Berswasembada Jagung. Available at http://agrimedia.mb.ipb.ac.id/. (Diakses pada tanggal 20 November 2016).

Purwanto, Zasli. (2008). Analisis Fungsi Keuntungan dan Efisiensi Relatif pada Usahatani Padi Sawah Tadah Hujan (Studi Kasus di Wilayah Prima Tani ds Bunbarat Kec. Rubaru Kab. Sumenep). Tesis. Program Pasca Sarjana. UB. Malang. 
Prosiding Seminar Nasional Pembangunan dan Pendidikan Vokasi Pertanian

Politeknik Pembangunan Pertanian Manokwari, 14 November 2020

e ISSN : 2774-1982

Soekartawi. (1991). Agribisnis Teori dan Aplikasinya. CV. Rajawali Perss, Jakarta.

Subandi, M. Syam \& A. Widjojo. (1998). Jagung. Balai Penelitian Tanaman Pangan. Bogor 